Submitted $9^{\text {th }}$ Agustus 2021

Accepted 20 $0^{\text {th }}$ Agustus 2021

\title{
PELATIHAN MEMBUAT MENU MAKANAN PAGI "AMERICAN BREAKFAST" BAGI PEMILIK DAN PENGELOLA HOMESTAY DALAM PELATIHAN PENGELOLAAN OPERASIONAL HOMESTAY DI DESA WISATA TARO TEGALLALANG GIANYAR BALI
}

\author{
Ida Ayu Kalpikawati ${ }^{1}$, Ni Wayan Chintia Pinaria ${ }^{2}$, I Nyoman Sudiksa ${ }^{3}$ \\ Program Studi Bisnis Hospitaliti, Jurusan Hospitality, Politeknik Pariwisata Bali \\ idakalpika@yahoo.com ${ }^{1,}$ chintia_pinaria@yahoo.co.id ${ }^{2}$,nsudiksa@gmail.com ${ }^{3}$
}

\begin{abstract}
Taro Village has natural and cultural potential that can support the welfare of its people through tourism activities. To support the development of tourism in Taro Village, several houses have been developed into homestays by homeowners who are members of the Taro Village community, but not all of them are managed properly and operate optimally. One of the important skills that homestay owners and employee must have is preparing and making breakfast for tourists or staying guests. There are not many menu variations that can be prepared by homestay managers because of their limited skills and knowledge in preparing breakfast menus for guests. The Hospitality Business Study Program in collaboration with the lecturers of the Catering Management Study Program at the Bali Tourism Polytechnic provides training for homestay owners and employee in preparing an American breakfast menu to improve the competence of homestay owners and employee.
\end{abstract}

Keyword : tourism village, homestay, community service

\begin{abstract}
ABSTRAK
Desa Taro memiliki potensi alam dan budaya yang dapat mendukung kesejahteraan masyarakatnya melalui kegiatan pariwisata. Untuk mendukung perkembangan pariwisata di Desa Taro terdapat beberapa rumah telah dikembangkan menjadi homestay oleh pemilik rumah yang merupakan anggota masyarakat Desa Taro, namun belum seluruhnya dikelola dengan baik dan beroperasi secara maksimal. Salah satu keterampilan penting yang harus dimiliki pemilik dan pengelola homestay adalah menyiapkan dan membuat makanan pagi bagi wisatawan atau tamu yang menginap. Belum banyak variasi menu yang dapat disiapkan oleh pengelola homestay karena terbatasnya keterampilan dan pengetahuan mereka dalam menyiapkan menu makanan pagi bagi tamu. Program Studi Bisnis Hospitaliti bekerjasama dengan dosen Program Studi Manajemen Tata Boga Politeknik Pariwisata Bali memberikan pelatihan bagi pemilik dan pengelola homestay dalam menyiapkan menu makanan pagi American breakfast untuk meningkatkan kompetensi peserta pelatihan di bidang makanan.
\end{abstract}

Kata Kunci: desa wisata, homestay, pengabdian kepada masyarakat 


\section{LATAR BELAKANG}

Desa Wisata merupakan salah satu program Pembangunan Nasional yang dikembangkan oleh Kementerian Pariwisata Dan Ekonomi Kreatif yang dalam pelaksanaannya program Desa Wisata di Indonesia melibatkan peran serta masyarakat. Salah satu desa wisata di Indonesia yang turut melibatkan peran serta masyarakat dalam pengembangan pariwisata daerahnya, yaitu Desa Wisata Taro. Desa Wisata Taro terletak di Kecamatan Tegallalang, Kabupaten Gianyar, Bali. Desa Wisata Taro memiliki potensi alam dan budaya yang dapat mendukung kesejahteraan masyarakatnya melalui kegiatan pariwisata. Penduduk Desa Taro sangat mendukung adanya kegiatan wisata di desa mereka. Hal ini dapat dilihat dari perkembangan desa wisata Taro (DEWITA) pada situs resmi Ditjen Kemendesa RI yang telah menempati peringkat ke-4 secara nasional dalam penghargaan Desa Wisata Nusantara pada tahun 2019. Pada bulan September 2021 Desa Taro telah berhasil meraih juara I penghargaan BCA Desa Wisata Award 2021 kategori alam (Gatra.com, 2021)

Pengembangan pariwisata di suatu desa wisata, memerlukan adanya strategi pengembangan seperti aspek amenitas sebagai sarana tempat tinggal bagi pengunjung, baik yang bersifat sementara (half day visit) maupun yang tinggal dalam jangka waktu yang lama. Salah satu bentuk sarana amenitas yang dikembangkan di Desa Wisata Taro adalah homestay. Penerapan konsep homestay di Desa Wisata Taro berbasis Tri Hita Karana sebagai implementasi dari konsep pariwisata yang dikembangkan yaitu Eco Spiritual Destination. Konsep homestay yang dikembangkan berbasis Tri Hita Karana menjadi Unique Selling Point (USP) untuk menarik minat tamu menginap di homestay tersebut.

Homestay merupakan usaha masyarakat lokal yang terbentuk dari hasil pemberdayaan masyarakat dalam pengembangan pariwisata berbasis masyarakat (Suharto, 2017). Menurut Gangotia (dalam Bham 2014), homestay yang dikelola oleh masyarakat dapat menjadi manfaat penting untuk pemerintah daerah dalam membantu meningkatkan perekonomian daerah dan secara tidak langsung membantu memperkenalkan kawasan tersebut ke masyarakat luas. Para tamu yang menginap di homestay mendapatkan kesempatan untuk meluangkan waktu bersama keluarganya, maupun bersama keluarga pemilik homestay dalam menikmati adat istiadat, nilai, budaya serta kehidupan masyarakat pedesaan.

Perkembangan pariwisata yang sangat cepat dari Desa Wisata Taro belum didukung dengan keberadaan sarana akomodasi yang memadai untuk wisatawan menginap. Terdapat beberapa rumah telah dikembangkan menjadi homestay oleh pemilik rumah yang merupakan anggota masyarakat Desa Taro, namun belum seluruhnya dikelola dengan baik dan beroperasi secara maksimal karena terbatasnya kemampuan SDM pemilik dan karyawan homestay, serta belum didukung dengan fasilitas yang memadai untuk mendukung berjalannya operasional homestay di Desa Wisata Taro. Hal ini disampaikan oleh Ketua Pokdarwis Desa Wisata Taro dan Perbekel Desa Taro dalam penjajagan ke lokasi oleh Program Studi Bisnis Hospitaliti Politeknik Pariwisata Bali pada tanggal 16-17 Desember 2021.

Salah satu keterampilan penting yang harus dimiliki pemilik dan pengelola homestay adalah menyiapkan dan membuat makanan pagi bagi wisatawan atau tamu yang menginap, berdasarkan observasi menu makanan pagi yang disiapkan oleh karyawan homestay masih berupa menu lokal seperti bubur bali, jajanan bali dan sesekali nasi goreng sesuai permintaan tamu. Belum banyak variasi menu yang dapat disiapkan oleh pengelola homestay karena terbatasnya keterampilan dan pengetahuan mereka dalam 
menyiapkan menu makanan pagi bagi tamu. Dengan perkembangan pariwisata Desa Wisata Taro yang begitu cepat tentu akan diikuti dengan meningkatnya minat wisatawan untuk menginap di homestay di Desa Wisata Taro sehingga pemilik dan pengelola homestay dituntut agar memiliki kualitas dan kemampuan dalam menyiapkan menu makanan pagi yang lebih bervariasi dan berkualitas. Berdasarkan analisis situasi tersebut maka pelatihan menyiapkan menu makanan pagi "American Breakfast"dilaksanakan di Desa Wisata Taro Tegallalang Gianyar Bali.

\section{METODE DAN PELAKSANAAN KEGIATAN}

Pelatihan menyiapkan menu makanan pagi "American Breakfast" merupakan bagian dari Pelatihan Pengelolaan Operasional Homestay di Desa Wisata Taro Tegallalang Gianyar yang telah dilaksanakan dengan durasi waktu pelatihan 64 jam. Bidang pelatihan meliputi pelayanan bidang housekeeping, pelayanan bidang makanan dan minuman (services) dan pelatihan bidang tata boga serta materi untuk meningkatkan kualitas pelayanan, kegiatan promosi, dan penjualan homestay.

Untuk pelatihan bidang tata boga materi yang disajikan berupa teori yaitu 6 jam pelatihan meliputi : higiene dan sanitasi, penerapan CHSE di homestay, perencanaan menu dan praktik (8jam) menyiapkan menu makanan pagi berupa "American Breakfast". Durasi pelatihan total untuk bidang tata boga ini adalah 14 jam pelatihan, dilaksanakan pada hari ke-5 dan ke-6 pada tanggal 9-10 April 2021 bertempat di Venus One Tourism Academy (VOTA) Tegalalang Gianyar.

Fasilitator dalam kegiatan pelatihan adalah dosen Program Studi Bisnis Hospitaliti bekerja sama dengan dosen Program Studi Manajemen Tata Boga Politeknik Pariwisata Bali.

\subsection{Peralatan dan Bahan}

Breakfast atau sarapan adalah kegiatan untuk mengonsumsi hidangan utama pada pagi hari. Waktu sarapan dimulai dari pukul 06.00 pagi sampai dengan pukul 10.00 pagi menu "American Breakfast" merupakan salah satu hidangan makan pagi yang merupakan bagian dari beberapa kelompok makanan yang biasa dihidangkan saat makan pagi. Menu "American Breakfast" yang dipraktikkan adalah hidangan telur meliputi : boiled eggs (soft, medium, hard) poach eggs, fried eggs, scrambled eggs, poach eggs dan omelette.

a. Persiapan Peralatan:

Stove, sauce pan, bowl, cutting board, knife, tray, toaster, teflon, plate, spoon, fork, spatula, ballon whisk, dll

b. Persiapa bahan-bahan yang diperlukan meliputi :

Eggs, ham, bacon, sausage, bread, french fries, tomato, bell pepper, lettuce, vinegar, salt and pepper.

\section{METODE PELATIHAN}

Kegiatan pelatihan menyiapkan menu makanan pagi "American Breakfast" ini dilakukan dengan beberapa metode sebagai berikut :

a. Presentasi/ceramah

1) Higiene dan Sanitasi dan Penerapan CHSE di Homestay

Pada tahap awal pelaksanaan pelatihan, fasilitator menggunakan metode ceramah dengan memberikan penjelasan tentang higiene dan sanitasi dalam pengolahan makanan serta penerapan CHSE (Cleanliness, Healthy, Safety, Environment): Kebersihan, Kesehatan, Keselamatan dan Kelestarian 
Lingkungan bagi pemilik dan pengelola akomodasi pariwisata (homestay/pondok wisata) yang mengacu pada pedoman CHSE dari Kemenparekraf RI (2020). Pemahaman tentang CHSE merupakan aspek penting dalam persiapan tenaga pengolah makanan yang profesional yaitu pengetahuan dan keterampilan mengenai cara-cara pengolahan makanan serta perilaku bekerja yang bersih sesuai dengan penerapan higiene sanitasi, sehingga menghasilkan makanan yang enak, penampilan yang menarik, bersih dan aman untuk dikonsumsi bagi wisatawan.

2) Perencanaan Menu

Materi kedua yang dijelaskan oleh fasilitator adalah tentang perencanaan menu meliputi : difinisi menu, sejarah menu, tipe menu, fungsi menu, lis menu (daftar makanan yang tersedia untuk tamu) dan bagaimana merencanakan menu breakfast. Merencanakan menu sangat penting untuk dipahami terutama bagi pengelola homestay.

b. Demonstrasi

Fasilitator sebagai instruktur pelatihan melaksanakan demonstrasi memasak menu makanan pagi "American Breakfast" seperti boiled eggs (soft, medium, hard) poach eggs, fried eggs, scrambled eggs, poach eggs dan omelette untuk memberikan contoh dalam pengolahan makanan bagi peserta pelatihan .

c. Praktik Langsung dari Peserta

Para peserta diberikan kesempatan untuk praktik membuat makanan pagi secara langsung setelah menyaksikan demonstrasi oleh instruktur pelatihan. Dalam praktik memasak peserta dibagi dalam 2 kelompok masing-masing kelompok terdiri dari 5-6 orang. Kelompok 1 ditugaskan oleh instruktur membuat menu : scrambled eggs dan fried eggs kelompok 2 menyiapkan : omelette dan poach eggs. Hasil praktik dipresentasikan dan dievaluasi oleh instruktur untuk mendapat masukan. Akhir pelatihan para peserta menikmati hasil praktik mereka.

\section{HASIL DAN PEMBAHASAN}

Kegiatan pelatihan menyiapkan menu makanan pagi bagi pemilik dan karyawan homestay dalam Pelatihan Pengelolaan Operasional Homestay Di Desa Wisata Taro Tegallalang Gianyar Bali telah berjalan dengan lancar walaupun saat pelatihan peserta sedikit terlambat dari waktu yang telah ditentukan karena tempat pelatihan bertempat di Venus One Tourism Academy (VOTA) yang berlokasi di Tegallalang Gianyar sekitar 30 menit perjalanan dari Desa Wisata Taro. VOTA dipilih sebagai lokasi pelatihan dengan pertimbangan dari Ketua Pokdarwis Desa Wisata Taro bahwa VOTA sebagai sebuah Akademi Pariwisata memiliki sarana serta peralatan dapur yang lengkap sehingga para peserta dapat mengikuti pelatihan memasak dengan baik dan peserta juga berkesempatan mengetahui fisik dapur dan jenis peralatan dapur sesuai persyaratan standar untuk sebuah akomodasi.

Pelatihan pertama untuk bidang makanan ini diisi dengan pemaparan materi berupa teori tentang higiene dan sanitasi, penerapan CHSE di homestay dan perencanaan menu. Keesokan harinya pelatihan dilanjutkan dengan praktik menyiapkan menu "American Breakfast". Sebelum pelatihan dimulai para peserta wajib mencuci tangan dan melaksanakan cek suhu sesuai dengan standar CHSE serta dihimbau selalu menjaga jarak saat pelatihan, hal ini penting karena kegiatan ini dilakukan pada masa pandemic Covid19. 
Jumlah peserta terdiri dari 11 orang merupakan pemilik dan pengelola homestay di Desa Wisata Taro Tegallalang Gianyar. Beberapa pemilik dan pengelola homestay juga merupakan anggota Pokdarwis Desa Wisata Taro. Jumlah peserta dibatasi karena durasi pelatihan untuk seluruh pelatihan pengelolaan operasional homestay ini meliputi bidang houskeeping, pelayanan makanan dan minuman dan bidang tata boga dan teori tentang pemasaran dan penjualan homestay berdurasi total 64 jam dengan 9x pelatihan. Harapan kedepannya dari Perbekel Desa Taro dan Ketua Pokdarwis Desa Wisata Taro bahwa para peserta pelatihan ini diharapkan akan menjadi kader dalam perkembangan dan pengelolaan homestay di Desa Wisata Taro Tegallalang Gianyar.

Perbekel Desa Taro dalam sambutannya menyampaikan apresiasi dan perasaan senang karena pelatihan ini sangat dirasakan manfaatnya bagi masyarakat pelaku wisata di Desa Wisata Taro khususnya pemilik dan pengelola homestay. Dalam sambutannya, Perbekel Desa Taro juga menginginkan kegiatan pelatihan serupa bisa diselenggarakan kembali kedepannya. Berikut ini adalah beberapa dokumentasi kegiatan pelatihan menyiapkan menu "American Breakfast" :
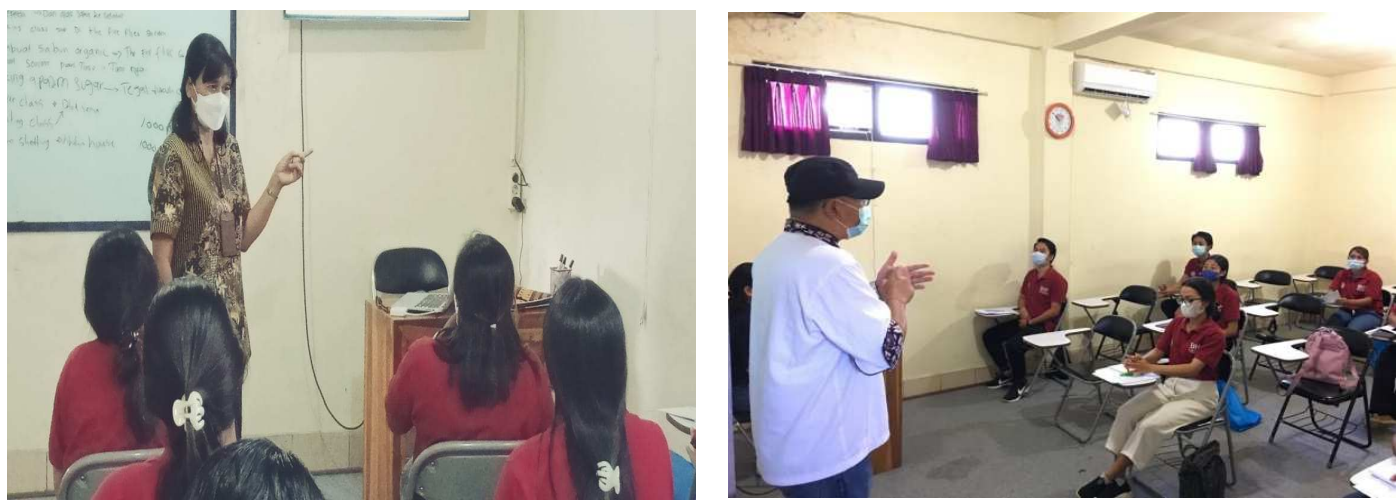

Sumber : Dokumentasi Penulis (2021)

Gambar 1.

Pemberian Materi Hygiene Sanitasi dan Penerapan CHSE serta Materi Perencanaan Menu oleh Fasilitator
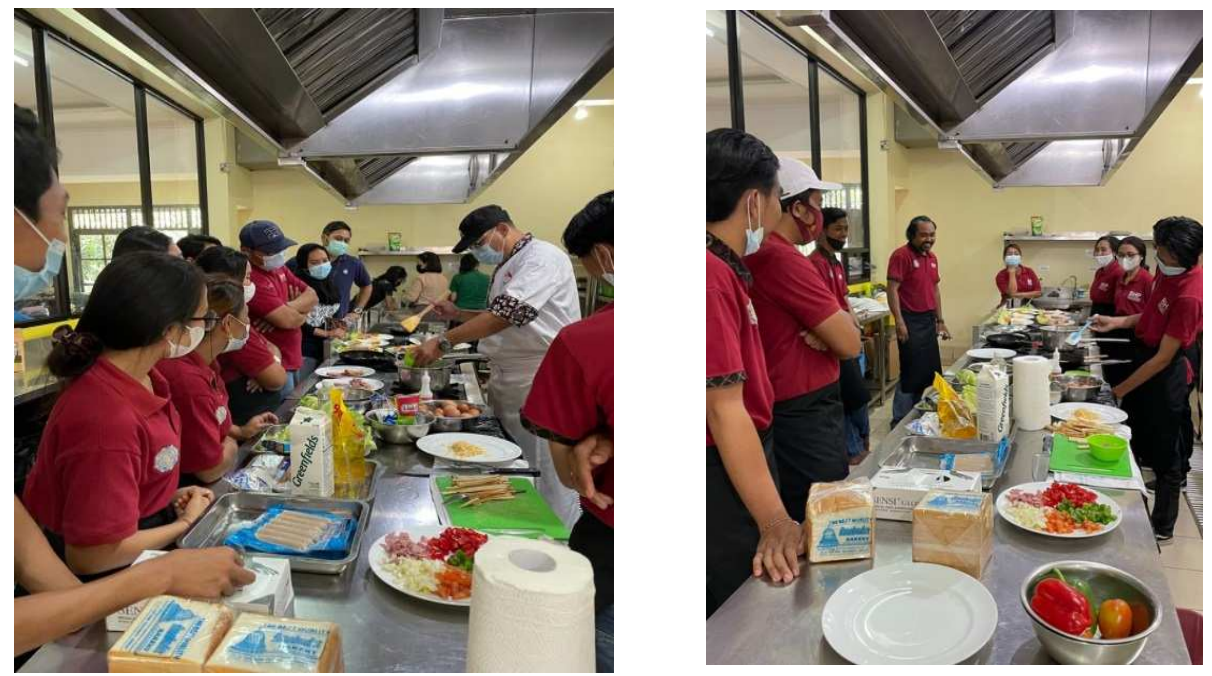

Sumber : Dokumentasi Penulis (2021)

Gambar 2.

Demontrasi memasak Menu American Breakfast oleh Instruktur diperhatikan dengan penuh perhatian dan dipraktikkan oleh seluruh peserta pelatihan 


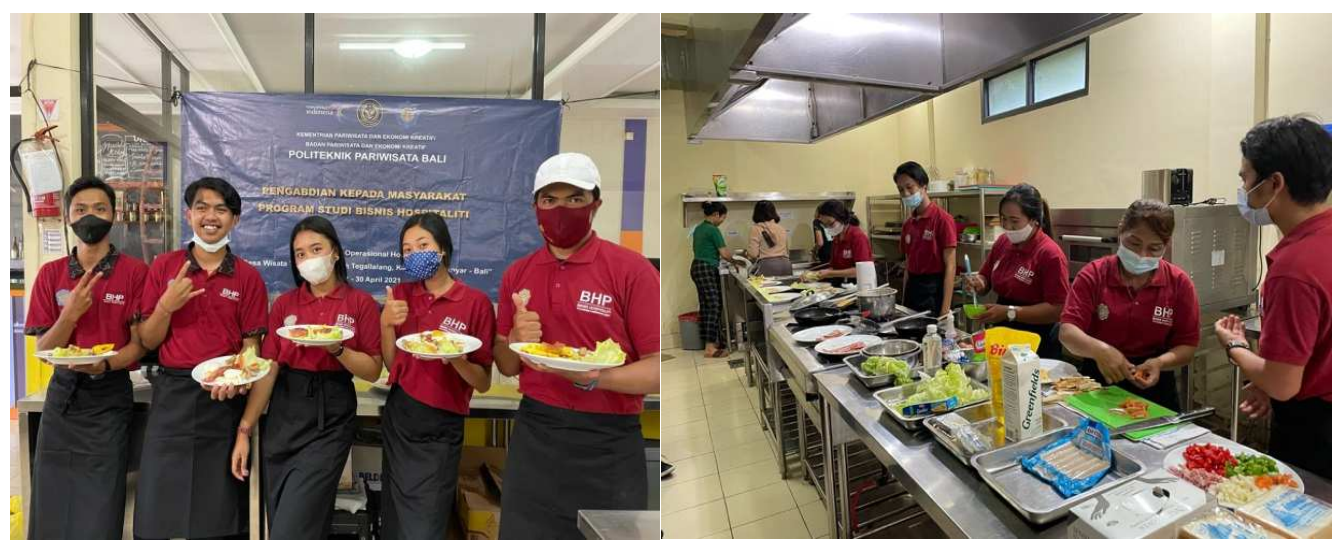

Sumber : Dokumentasi Penulis (2021)

Gambar 3.

Para Peserta Praktik menyiapkan American Breakfast dan Presentasi makanan dari kelompok 1 dan kelompok 2

\section{EVALUASI KEGIATAN PELATIHAN}

Untuk mengetahui efektifitas pelaksanaan program Pengabdian Kepada Masyarakat maka dilakukan evaluasi. Evalaluasi dilakukan dengan meminta umpan balik dari para peserta pelatihan melalui angket atau kuesioner. Umpan balik dan pendapat peserta pelatihan terklasifikasi dalam; pernyataan kepuasan secara umum terhadap kegiatan pelatihan, pelaksanaan teknis kegiatan, materi pelatihan, saran bagi pelatihan di masa depan, dan rencana peserta setelah pelatihan. Adapun paparan dari evaluasi yang diberikan peserta adalah sebagai berikut;

Peserta pelatihan yang terdiri dari 11 orang secara umum menyatakan puas terhadap kegiatan pelatihan, dimana 11 orang menyatakan sangat puas dan 1 orang menyatakan puas. Peserta juga menyatakan bahwa materi pelatihan yang diberikan sangat cocok dengan kebutuhan peserta. Dengan materi pelatihan yang diberikan peserta bermaksud untuk menyediakan menu "American Breakfast" sebagai menu pilihan makan pagi pada homestay yang mereka kelola. Peserta juga berharap dapat berpartisipasi dalam meningkatkan kompetensi masyarakat Desa Wisata Taro dalam pengembangan akomodasi khususnya homestay.

Sehubungan dengan pelaksanaan kegiatan pelatihan, secara teknis peserta menyatakan sangat puas terhadap seluruh rangkaian kegiatan mulai dari acara pembukaan, koordinasi dan komunikasi, kegiatan praktik, tempat pelatihan, kudapan (snack) dan makan siang dan acara penutupan kegiatan. Dengan demikian, peserta berharap bahwa pelatihan sejenis ini dapat dilakukan di masa yang akan datang.

Peserta pelatihan memberikan penilaian yang sangat baik terhadap materi pelatihan yang didiskusikan dan dipraktikkan selama kegiatan pelatihan. Sebagian besar peserta meynatakan mahwa materi pelatihan yang diberikan sangat relevan dengan kebutuhan yang mereka. Materi pelatihan higiene dan sanitasi, penerapan CHSE di homestay, perencanaan menu, serta praktik memproduksi makanan pagi, dinyatakan sangat relevan untuk peningkatan kompetensi dalam mengelola operasional homestay khususnya di bidang makanan. 
Semua peserta menyatakan setelah mengikuti pelatihan merasa mendapatkan tambahan pengetahuan, wawasan, dan keterampilan, kegiatan pelatihan dinyatakan sangat positif, penyajian yang baik dari fasilitator sehingga mudah untuk dipahami dan dilaksanakan. Pada akhirnya peserta berpendapat bahwa pelatihan menjadi penting untuk dilaksanakan di masa yang akan datang.

\section{SIMPULAN}

Pelatihan menyiapkan menu makanan pagi "American Brakfast" bagi pemilik dan pengelola homestay di Desa Wisata Taro Tegalalang Gianyar terlaksana dengan baik dan sesuai dengan yang diharapkan. Jumlah peserta pelatihan adalah 11 orang merupakan pemilik dan pengelola homestay di Desa Wisata Taro Tegallalang Gianyar. Para peserta sangat antusias selama mengikuti kegiatan pelatihan khususnya dalam mempraktikkan secara langsung metode memasak "American Breakfast" yang telah diberikan oleh instruktur.

Para peserta secara umum menyatakan sangat puas terhadap seluruh rangkaian kegiatan mulai dari acara pembukaan, koordinasi, komunikasi, kegiatan praktik, tempat pelatihan, kudapan (snack) dan makan siang dan acara penutupan kegiatan. Penyajian materi yang baik dari fasilitator serta materi yang disajikan dirasa sangat relevan dengan kebutuhan peserta untuk peningkatan kompetensi dalam mengelola operasional homestay pada umumnya dan khusunya dalam pengelolaan makanan menu makanan pagi bagi tamu.

\section{PERNYATAAN PENGHARGAAN}

Dalam kesempatan ini Penulis mengucapkan terima kasih sedalam-dalamnya kepada :

a. Direktur Politeknik Pariwisata Bali atas support yang luar biasa dan beberapa kali ikut hadir dalam pelaksanaan pelatihan.

b. Pusat Penelitian dan Pengabdian Kepada Masyarakat (P3M) Politeknik Pariwisata Bali yang telah mendukung kegiatan ini baik berupa pendanaan dan arahan sehingga pelatihan ini dapat terlaksana dengan baik dari perencanaan, pelaksanaan maupun pelaporan.

c. Perbekel Desa Taro, Pokdarwis Desa Wisata Taro, seluruh Dosen Program Studi Bisnis Hospitaliti dan Dosen Manajemen Tata Boga Politeknik Pariwisata Bali yang telah membantu proses pelaksanaan kegiatan ini.

d. Mahasiswa Program Studi Bisnis Hospitaliti Politeknik Pariwisata Bali yang telah membantu pelaksanaan kegiatan pelatihan.

e. Masyarakat Desa Wisata Taro khususnya peserta pelatihan, semoga pelatihan ini bermanfaat dan kedepannya bisa menjadi kader-kader bagi perkembangan homestay di Desa Wisata Taro Tegallalang Gianyar Bali.

\section{DAFTAR PUSTAKA}

ASEAN Homestay Standard. (2016). Jakarta: ASEAN Secretariat.

Bhan, Suraj. 2014. Homestay Tourism in India: Opportunities and Challenges. African Journal of Hospitality, Tourism and Leisure Vol. 3 (2) - (2014) ISSN: 2223-814X. Kurukshetra University, Kurukshetra Haryana, India

Hasil Aplikasi Bisnis Hospitaliti. 2021. Identifikasi Potensi Homestay di Desa Wisata Taro Tegallalang Gianyar Bali. Politeknik Pariwisata Bali. 
Gatra.com.2021. Berikut Nama Pemenang BCA Desa Wisata Awards 2021. www.gatra.com

Kementerian Pariwisata dan Ekonomi Kreatif/ Badan Pariwisata dan Ekonomi Kreatif. 2020. Panduan Pelaksanaan Kebersihan, Kesehatan, Keselamatan dan Kelestarian Lingkungan Homestay/Pondok Wisata. Dalam Rangka Melaksanakan Protokol Kesehatan Bagi Masyarakat Produktif Untuk Pencegahan dan Pengendalian Corona Virus Disease 2019 (Covid-19).

Suharto, S. (2017). Empowerment Strategy Masyarakat Desa Wisata Kebonagung Kecamatan Imogiri Kabupaten Bantul Yogyakarta. Wahana Informasi Pariwisata: Media Wisata, 15(1) 